\begin{tabular}{|l|l|l||}
\hline \multicolumn{2}{|c|}{ PublisherInfo } \\
\hline \hline PublisherName & $:$ & BioMed Central \\
\hline \hline PublisherLocation & $:$ & London \\
\hline \hline PublisherImprintName & $:$ & BioMed Central \\
\hline \hline
\end{tabular}

\title{
A Journal Club on the Web
}

\begin{tabular}{||l|l|l||}
\hline \multicolumn{2}{|c|}{ ArticleInfo } \\
\hline \hline ArticleID & $:$ & 4295 \\
\hline \hline ArticleDOI & $:$ & $10.1186 /$ ccf-2000-webreport1864 \\
\hline \hline ArticleCitationID & $:$ & webreport1864 \\
\hline \hline ArticleSequenceNumber & $:$ & 36 \\
\hline \hline ArticleCategory & $:$ & Web report \\
\hline \hline ArticleFirstPage & $:$ & 1 \\
\hline \hline ArticleLastPage & $:$ & 3 \\
\hline \hline & & RegistrationDate : 2000-10-20 \\
ArticleHistory & $:$ & OnlineDate $\quad$ 2000-10-20 \\
\hline \hline ArticleCopyright & $:$ & Current Science Ltd2000 \\
\hline \hline ArticleGrants & $:$ & \\
\hline \hline ArticleContext & $:$ & 1305444 \\
\hline \hline
\end{tabular}




\section{Overview}

This site is an interactive medical journal club where health care professionals can go to discuss articles published in the medical literature. The site was created in 1995 by Dr. Michael Jacobson who periodically summarises articles from the medical literature and puts them up on the site. He adds his own comments about the articles and then invites readers to give their feedback, an intrinsic part of the journal club. In addition, a number of authors of the articles reviewed have participated in the discussions. The articles discussed are primarily in the field of adult internal medicine and are searchable by subject.

\section{Content}

The site is very simple to navigate and appears to be popular with the healthcare community, boasting 3,000 visitors per week. Journal Club also alerts vistors by email when new summaries are posted on the site.

\section{Other comments}

5th September 2000

\section{Evaluation}

None 


\section{References}

1. Journal Club. [http://www.journalclub.org]

This PDF file was created after publication. 